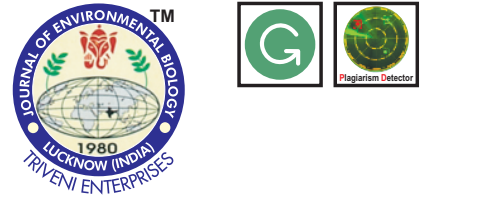

\title{
Modelling land use/cover change in Lake Mogan and surroundings using CA-Markov Chain Analysis
}

\section{Authors Info}

\section{Z.O. Durmusoglu* and}

\section{A.A. Tanriover ${ }^{2}$}

${ }^{1}$ Department of Urban and Regional Planning, Faculty of Architecture, Gazi University, Ankara, 06570, Turkey

${ }^{2}$ Department of Urban and Regional Planning, Faculty of Natural Sciences, Architecture and Engineering, Bursa Technical University, Bursa, 16330, Turkey

*Corresponding Author Email : azokaydurmusoglu@gmail.com

Key words

CA-Markov Chain Analysis,

Change detection,

Modelling,

Lake Mogan,

Land use/cover change

Publication Info

Paper received : 21.08.2016

Revised received : 25.06 .2017

Accepted : 28.06.2017

\section{Abstract}

Aim : Lake Mogan, having high ecological and cultural significance, has been under intense pressure of urbanization and industrialization due to its location on the periphery of the capital Ankara. In this study, we analyzed data from satellite remote sensing, Geographic Information System and Cellular Automata Markov Chain modelling to predict land use/cover changes in Lake Mogan and surrounding areas.

Methodology : Three images recorded in 1975 and 1999 (air photos) and 2009 (Quickbird image) were used to detect the land use/cover changes over the time. An object-based supervised classification approach to simulate changes in the study area for the future was performed. Land use/cover changes for the year 2029 was modelled using Cellular Automata Markov Chain Analysis with the support of suitability analysis.

Results : The results indicated that most of the agricultural areas will be converted into settlements over the next 40 years. Modelling results for 2029 also showed that land degradation activities are likely to continue in the future.

Interpretation : According to model on land use changes in Lake Mogan and surrounding areas, there is an immediate need to take long-term measures for sustainable land development based on the regional scales, preferably on the basin level.

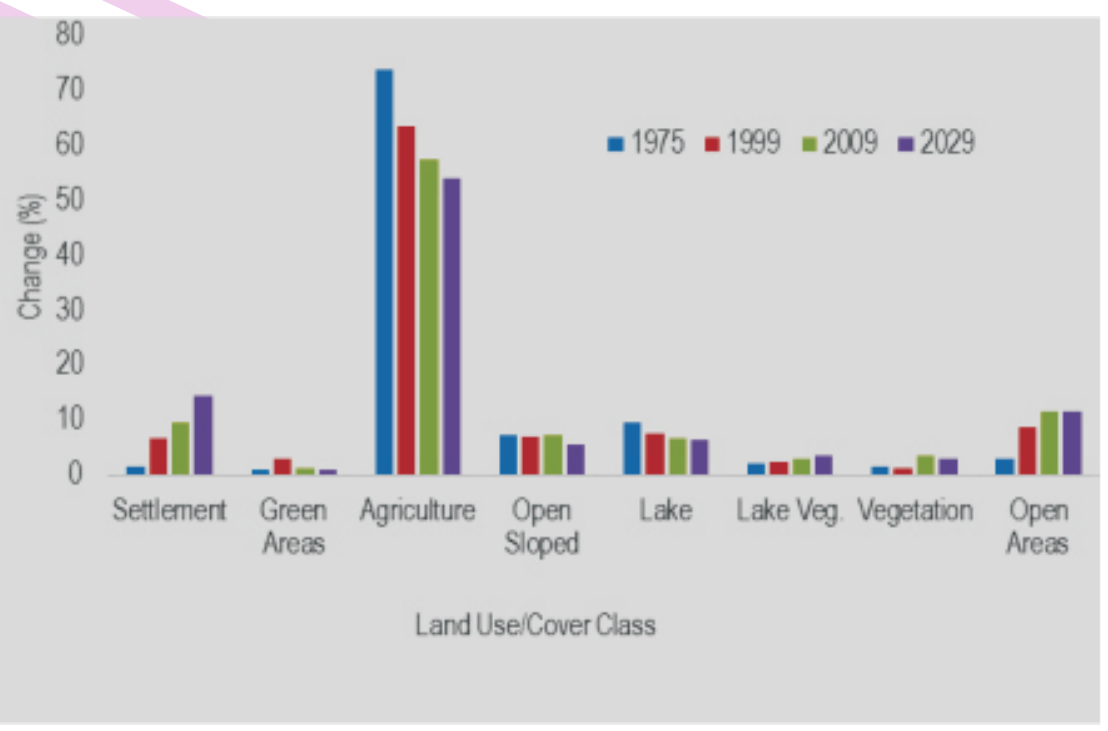




\section{Introduction}

For centuries, almost all of the Earth's ecosystems have been significantly altered by human activities, either directly or indirectly. These changes in the structure and functioning of the ecosystems have occurred faster and more extensively in the last century than in any period in human history (Vitousek et al., 1997; Chapin et al., 2011). Over the past few decades, doubling of human population (Cohen, 2002) associated with industrial activities and urbanization has created pressures on the environment worldwide (Antrop, 2004; Arora et al., 2017; Vitousek et al., 1997). Rapid and extensive urban growth accompanied by the economic activities results in the necessity of more land for housing, public infrastructure, industrial and commercial developments (Weng, 2007), which results in changes in land use/cover (Long et al., 2007), but in turn causes profound impact on the environment (Turner and Meyer, 1994). Land use/cover changes are a global concern due to their adverse effects on climate (Foley et al., 2000; Foley et al., 2005; Pielke, 2005), biodiversity (Sala et al., 2000; Rizzoli, 2003), biogeochemical cycle (Pouyat et al., 2007; Klumpp et al., 2009; Schneck et al., 2015) and hydrology (Matheussen et al., 2000; Tu, 2006).

The focus on global issues relies significantly on understanding the structures and functions of ecosystems at local and regional scales (Aspinall and Hill, 2008). The changes in land use/cover at both scales will result in considerable global consequences (Lambin and Geist, 2006; Verburg et al., 2010). Identification of past and current information on the spatial and temporal dynamics of land use/cover and projecting these changes in the future play an essential role in decision making and long term planning (Brown et al., 2015).

Over the last decades, change detection techniques in conjunction with satellite remote sensing and geographical information systems (GIS) have made it possible to monitor and assess the magnitude, spatial distribution and type of land use/cover change (Weng, 2002) in urban growth studies. The application of models has been growing in recent years to predict likely future changes (Lambin et al., 2000; Veldkamp and Lambin, 2001; Epstein et al., 2002; He et al., 2008) and its relationship with the underlying driving mechanisms (Verburg, 2006; Verburg et al., 2009). Numerous spatial models have been developed to identify and and forecast the possible dynamic urban features (Li and Yeh, 2002). CA-Markov Chain Simulation, the integration of Cellular Automata and Markov Chain methods are the most effective and widely used modelling approaches. The process analyzes spatial changes from period to another and uses this information as the basis to project future changes (Araya and Cabral, 2010).

The Gölbaşı District, about $20 \mathrm{~km}$ away from the city center of Ankara, the capital of Turkey, represents a case of dense population, fast population growth and rapid changes in land use/cover. Since 1980's, Lake Mogan and the surrounding area, located in Gölbaşı District, have been subjected to serious environmental degradation because of intense urbanization and industrialization associated with human population growth and demand for housing, infrastructure and development of new agricultural lands. Lake Mogan, one of the wetlands of Turkey, has also been faced with increasing water pollution (Pulatsu and Aydın, 1997; Beklioglu, 2000; Barbaros et al., 2007).

Although, an increasing number of research has been carried out on water quality assessment of Lake Mogan (Karul et al., 2000; Fakıoglu and Pulatsu, 2005; Barbaros et al., 2007), very few studies have focused on the analysis of land use/cover changes in the basin (Durmusoglu, 2010). Identification of past and current information on land use /cover change provide possible future trajectories of change for the land managers and decision makers (Aspinall and Hill, 2008) and possibilities for better management of the site.

In this study, an integrated approach incorporating remote sensing, GIS and CA-Markov Chain Analysis was applied to analyze the changes in land use/cover in Lake Mogan and the surrounding area between the years 1975 and 2009 and predict the direction of the probable developments in the following years.

\section{Materials and Methods}

Study area : The selected area for this study, Mogan Lake and the surrounding, is located in Gölbaşı Basin in the south of Ankara, the capital of Turkey. It is approximately $20 \mathrm{~km}$ far away from the city center of Ankara. Although the main activity in the basin is agriculture, Mogan Lake and the surrounding area enable recreational and aesthetic opportunities for the inhabitants of Gölbaşı and Ankara. Gölbaşı Basin embraces Mogan and Eymir Lake, a delicate ecosystem formed by both aquatic and terrestrial ecosystems with its water resources, land forms, location and soil type, climate and biological richness. Lake Mogan is considered as watershed system of Ankara and is one of the important natural areas supporting the ecological sustainability of the city.

In addion to that, the lake and the surrounding wet and moorland areas accomodate rich and diverse floral and faunal species by providing water and primary production for their survival. In the Mogan Lake and surrounding areas, 488 terrestrial plant species have been identified, 52 of them are endemic. Around 200 different bird species were also determined in the area, 22 of them are raptors (OCKKB, 2010).

Since 1980's Mogan Lake and the surrounding area have been subjected to serious environmental degradation because of intense urbanization and industrialization associated with human population growth and demand for housing, infrastructure and development of new agricultural lands. In addition, a considerable 
Table 1 : Description of land use/cover classes used in the classisfication

\begin{tabular}{ll}
\hline Land cover classes & Descriptions \\
\hline Settlement & All residential, commercial and industrial areas \\
Green areas & Recreational areas in settlements \\
Agriculture & Cropland, horticultural farms and fruit orchards \\
Open slope & Sloped areas on hills and mountains \\
Road & Main and secondary transportation infrastructure \\
Lake & Lake Mogan, permenant and seasonal wet and moorlands \\
Lake vegetation & Submerged and emergent aquatic vegetation \\
Vegetation & Decidious, coniferous and mixed forest, shrubs, grassland \\
Open area & Bare areas and quarries \\
\hline
\end{tabular}

Table 2: Boolean approach criteria for development

\begin{tabular}{ll}
\hline Change drivers & Descriptions \\
\hline Distance from water & $\begin{array}{l}\text { A protection buffer of } 100 \mathrm{~m} \text { from the lake and the areas within the } 100 \mathrm{~m} \text { of the water were } \\
\text { considered unsuitable. }\end{array}$ \\
Distance from urban areas & $\begin{array}{l}\text { Areas close to existing developed areas are more suitable than the areas far from undeveloped } \\
\text { areas. }\end{array}$ \\
Distance from roads & Areas within $500 \mathrm{~m}$ of major road network were considered suitable. \\
Elevation of the land & As the altitude of elevation increases, the area is considered unsuitable \\
\hline
\end{tabular}

amount of domestic sewages, solid wastes from industry, and herbicides and pesticides from agricultural practices are being introduced directly into the Mogan Lake or the creeks feeding the lake and result in surface and ground water pollution. Besides, the sediment transported by erosion, snowmelt and drainage through the creeks causes serious increase in eutrophication level in the lake.

Even though Lake Mogan and its surroundings were declared as a "Special Environment Protected Area" by the Minister of Environment of Turkey in 1990 because of having important and rich biodiversity and fragile ecosystem, the negative effects of these degradation still continue.

Data set : The data set for the study comprised remotely sensed images recorded in 1975 (0.30 m spatial resolution aerial photos) and 1999 (0.60 m spatial resolution aerial photos) and 2009 Quickbird image (0.75 m spatial resolution). In addition 1:25,000 scale topographic and agricultural map were integrated into the data set.

Pre-procesing : The images were geometrically corrected and geocoded to the Universal Transverse Mercator (UTM) coordinate system using a reference image and 17 regularly distributed ground points (GCPs) selected from the remotely sensed images and air photos. Resampling used as a nearestneighbour algorithm and the transformation had root mean square errors (RMSE) of between 0.3 and 0.5 pixels, indicating that the images were located with an accuracy of less than a pixel.
Object-based supervised image classification: Land use/cover data preparation is the first step of the land change analysis and modelling. Object-based supervised image classification method has been widely used for classification of land use/cover units from high resolution images since the final result is similar to the human visual interpretation of digital images (Rizvi and Mohan, 2011).

Creation of the land use/cover map involved objectbased supervised image classification of 1975 and 1999 air photos and 2009 Quikbird images by using Definiens software. The land use/cover classification map of the study area was corrected manually using the field survey records and categories were determined according to the objectives of the research in which settlement, green areas, agriculture, open slope, road, lake, lake vegetation, vegetation open areas were taken as land cover classes (Table 1).

Change detection : Change detection is a technique used to determine changes in land use/cover properties using remotely sensed images acquired on the same geographical area at different times (Singh, 1989). In this study, changes in land use/cover between successive dates including 2029 prediction map were detected by post-classification comparison. The postclassification comparison is one of the most commonly used change detection techniques that classifies multi-temporal images separately into thematic maps and then compares classified images on a pixel-by-pixel basis to identify changes (Zhou et al., 2008). The traditional post-classification cross 
Table 3 : Summary of land use/cover change statistics for 1975, 1999 and 2009

\begin{tabular}{llllllll}
\hline \multirow{2}{*}{$\begin{array}{l}\text { Land use/cover } \\
\text { class }\end{array}$} & \multicolumn{2}{c}{1975} & \multicolumn{2}{c}{1999} & \multicolumn{2}{c}{ 2009 } & \multicolumn{2}{c}{$\begin{array}{c}\text { Relative change } \\
\text { 1975-2009 (\%) }\end{array}$} \\
\cline { 2 - 8 } & Area (ha) & $\%$ & Area (ha) & $\%$ & Area (ha) & $\%$ & \% \\
\hline Settlement & 34 & 1.4 & 166 & 6.8 & 235 & 9.7 & 591.7 \\
Green areas & 23 & 0.9 & 72 & 3.0 & 28 & 1.2 & 0.2 \\
Agriculture & 1796 & 73.9 & 1545 & 63.5 & 1403 & 57.6 & -21.9 \\
Open Sloped & 181 & 7.4 & 170 & 7.0 & 175 & 7.2 & -3.3 \\
Lake & 231 & 9.5 & 184 & 7.6 & 161 & 6.6 & -30.3 \\
Lake Veg. & 53 & 2.2 & 59 & 2.4 & 70 & 2.9 & 32.0 \\
Vegetation & 40 & 1.6 & 28 & 1.2 & 82 & 3.4 & 51.2 \\
OpenAreas & 76 & 3.1 & 210 & 8.6 & 280 & 11.5 & 268.4 \\
\hline
\end{tabular}

Table 4 : Cross tabulation actual land cover in 2009 with stimulated land cover for 2020 (number of pixels)

\begin{tabular}{lllllllll}
\hline Probabilty matrix & \multicolumn{7}{c}{ 2029 LULC } \\
\hline 2009 LULC & Settlement & Green & Agriculture & Open Sloped & Road & Lake & Vegetation & Wetland \\
\hline Settlement & 1726766 & 100046 & 183475 & 3158 & 207 & 13560 & 157575 & 160445 \\
Green & 140225 & 51625 & 17207 & 0 & 369 & 6352 & 38906 & 20769 \\
Agriculture & 657918 & 127935 & 11375961 & 211356 & 23619 & 68255 & 268273 & 1296341 \\
O.Sloped & 32064 & 0 & 202402 & 1254129 & 0 & 0 & 94676 & 169036 \\
Road & 0 & 0 & 225036 & 0 & 1219000 & 152614 & 13767 & 0 \\
Lake & 0 & 0 & 41582 & 0 & 67990 & 465186 & 33099 & 95362 \\
Vegetation & 24901 & 0 & 180214 & 379324 & 0 & 0 & 115048 & 118056 \\
Wetland & 847086 & 64242 & 127100 & 0 & 43 & 21049 & 264732 & 1473734 \\
\end{tabular}

tabulation (Lunetta and Elvidge, 1999) was employed to establish "from-to" categories for 1975 to 2009 images, which was essential for the definition of land use/cover change trajectories.

Multi criteria evaluation : For suitability analysis Multi Criteria Evaluation (MCE) is widely used process. This technique combines variables with different methodologies and then transforms them into a suitability map output (Drobne and Lisec, 2009). In order to define potential lands to be considered for further development, all the variables, constraints and factors, were determined for the study area. A factor is a criterion that enhances the suitability of a specific alternative for the activity. On the other hand, a constraint is a feature or area that is not preferred in any way or considered unsuitable.

The constraints for this study are the locations where the development is not possible or not allowed. The constraints were standardized into Boolean character of 0 (not suitable) and 1 (suitable) as factors were standardized to continuous suitability values from 0 (least suitable) to 255 (most suitable). The constraints included water and existing urban areas (Table 2).

Distance from main roads, urban structure, water and digital elevation model (DEM) were determined as spatial variables in GIS environment in order to form suitability map (Fig.

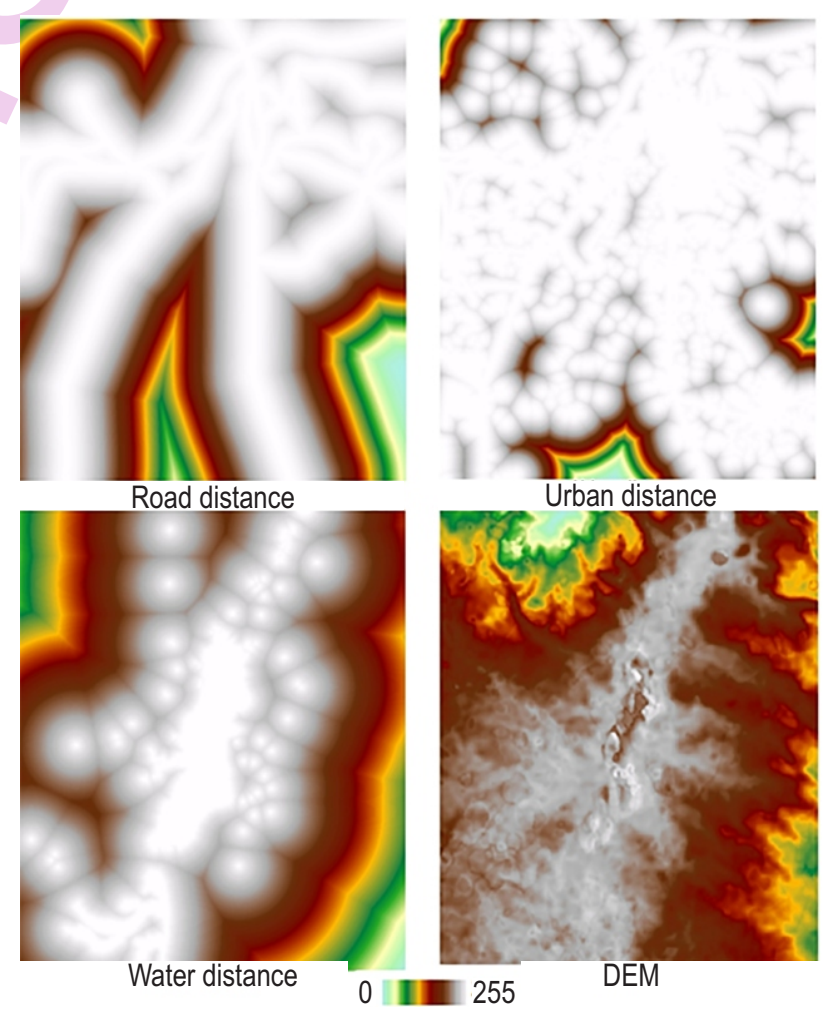

Fig. 1 : Standardized factors 
1). These factors were selected according to the relationships between the factors and the shape as the changing nature of structure. These factors were standardized into continuous variables by applying fuzzy set functions that are Sigmoidal, Jshaped and linear functions. The standardized suitability maps of each factor were defined in Fig.1. From the legend it can be observed that the white color represents the highest suitability which is 255 and the blue indicates the lowest suitability value which is 0 .

Cellular Automata (CA)-Markov Chain analysis and implementation of model : CA-Markov Chain analysis is the combination of CAand MARKOV methods and predicts the future state of a system based on its previous state (Baker, 1989; Weng, 2002; Fortin et al., 2003). The analysis describes the probability of land cover change from one period to another by developing a transition probability matrix between two discrete time periods.

In this study, land use/change maps produced from air photography and remotely sensed images recorded in 1975, 1999 and 2009 were used to derive land use change pattern. The images recorded in 1975 and 2009 were used to generate transition matrix for model calibration. Model was calibrated using multi-criteria analysis. The model generated output for 2009. This output then was compared with actual land use map resulted from 2009 image classification. The prediction accuracy was recorded as $69 \%$.

\section{Results and Discussion}

Change detection results : Classification maps, generated for 1975, 1999 and 2009 years are displayed (Fig.2) and the individual class area and change statistics for the years are summarized in Table 3. The visual interpretation of the images and the results of the statistics confirmed that a considerable change has occurred around the Lake Mogan since 1975.

From 1975 to 2009, urban settlements, lake vegetation and open areas increased to 201 ha (591.7\%), 17 ha (32\%) and 204 ha $(268.4 \%)$, respectively. In contrast, agricultural land, open sloped areas and the surface of the lake decreased by $393 \mathrm{ha}(21.88 \%), 6$ ha $(3.31 \%)$ and 70 ha (30.3\%). Relatively, developed areas and open areas increased $591.7 \%$ and $268.4 \%$ from 1975 to 2009 . The greatest increase occurred between 1975 and 1999, whereas agriculture and the surface of the lake decreased to $21.9 \%$ and $30.3 \%$ from 1975 to 2020 , respectively. The greatest decrease occurred similarly between 1975 and 1999 period (Fig. 2).

Settlements, agricultural and open areas, representing almost $80 \%$ of the total area are the major land cover types in the study area. Conversions involving these three classes also represent the most significant amount of change. Relatively, settlements grew by more than sixfold and open areas tripled between 1975 and 2009, with the greatest increase occurring from 1975 to 1999 , mainly at the expenses of surrounding agricultural areas (Table 3).

The visual interpretation of the images dated to 1975 indicates that the development in settlements, mainly limited to the northeastern part of the area, was minor. The results produced for 1999 clearly show that dramatic changes in the spatial distribution of the settlements took place around both the existing settlements and Mogan Lake, such that by the year 2009, a large-scale urban sprawl occurred in most parts of the study area. The construction of main highway, D-100 (previously called E-5) crossing Gölbaşı in particular promoted the development of industrial and residential areas. The initiation of second house developments around the Lake Mogan took in 1990's accelerated expansion process.

However, agricultural areas decreased gradually from 1975 to 2009 , and the relative loss rate reached up to $14 \%$ from 1975 to 1999 . The results produced for 1999 clearly indicate that the development of settlements was mainly at the expense of agricultural areas. It was observed from the images that the changes from agriculture to settlements occurred mostly near the highway and Mogan Lake.

The trend for both green areas and vegetation represented a fluctuation between a 34-year period. Green areas increased 49 ha (2.1\%) until 1999. As of this date, the areas 44 ha $(1.8 \%)$ decreased dramatically as the settlements took its place. On the contrary, vegetation decreased $12 \mathrm{ha}(0.4 \%)$ from 1975 to 1999 and a sharp increase occurred at 54 ha $(2.2 \%)$ between 1999 and 2009. The reason for the increase could be explained as afforestation process accelerated by Minister of Environment and Gölbaşı Municipality after Gölbaşı and its surrounding area were designated to be a "Specially Protected Area" in 1990.

The surface of the Lake Mogan showed a significant loss as the amount of lake vegetation in the vicinity of the lake increased. The extent of the lake and wetland may change from year to year due to varying precipitation and temperature.

Modelling results: After defining the parameters used for the calibration and modeling, the pattern and tendency of change in a long-term simulation were examined (Fig. 3). A cross-tabulation, that describes the changes in land cover classes included in the study, is given in Table 4. Here the number of pixels is expected to change from 2009 to 2029. The diagonal in the matrix indicates the number of pixels that have persisted during the simulation, while the off-diagonal showed the number pixels that changed class (Table 4.)

Modelling results for 2029 indicate that land degradation activities are likely to continue in the future. As a result agricultural encroachment, vegetation loses, decreases in lake and wetlands area and expansion settlements are predicted. Urban growth and the loss of agricultural land will be the most important conversions all over the study area, particularly around 

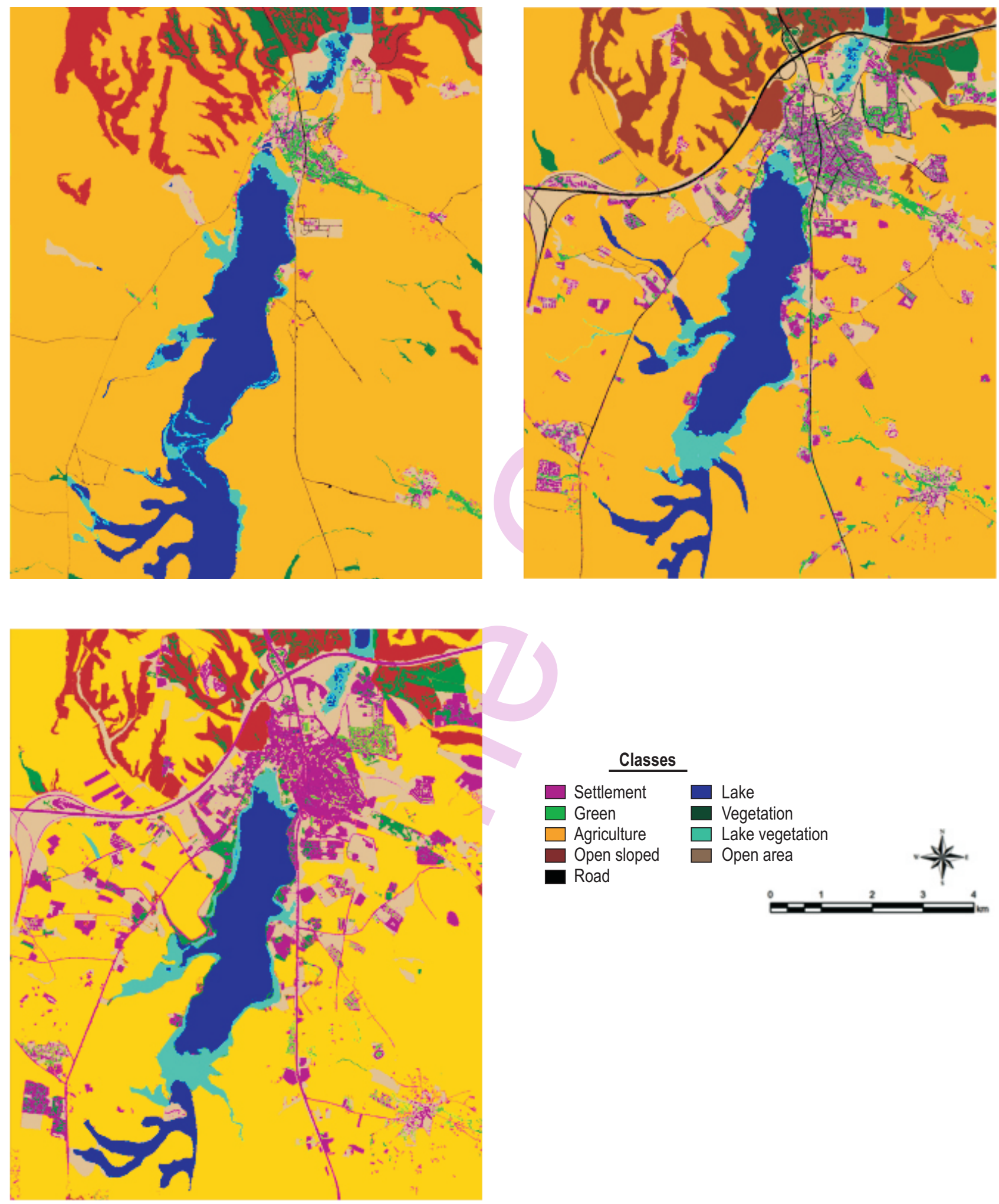

Fig. 2 : Object-based image classification results (A: 1975, B: 1999, C: 2009) 


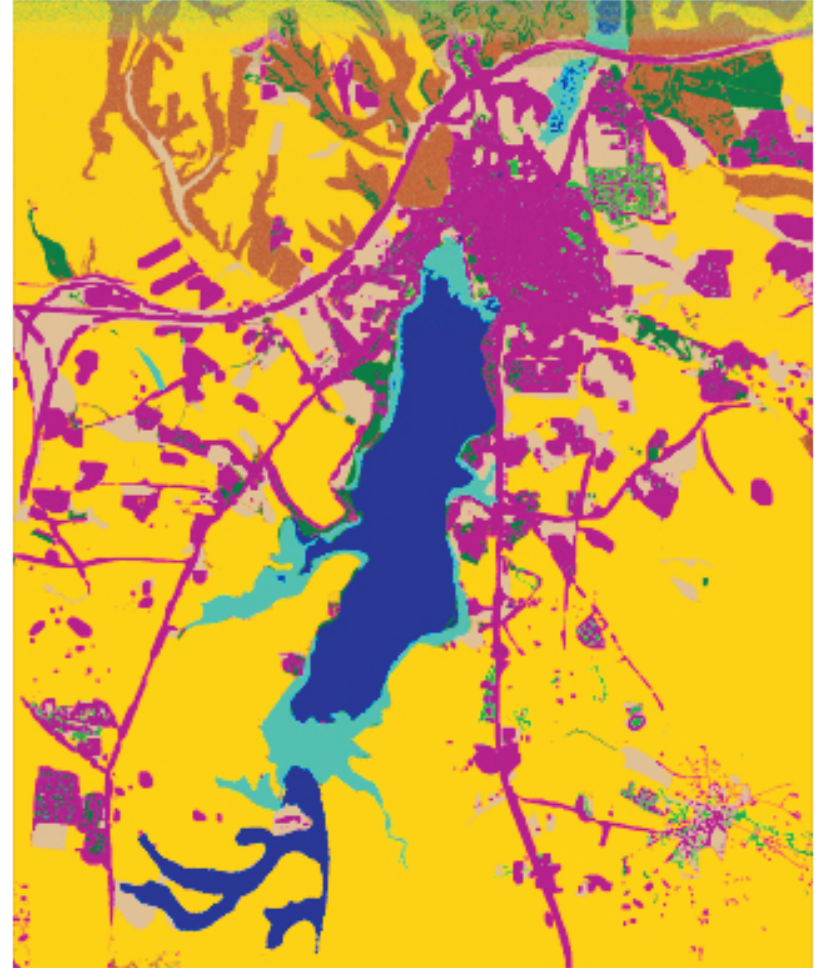

Fig. 3 : The land use/cover probability map of study area for 2029

Lake Mogan. In addition to these more highway construction was expected as the urban development spreads over the whole vicinity.

Ankara has been experiencing a considerable population growth since 1950's due to the industrial development and migration from the countryside. This situation significantly affects the rate of urban sprawl and expansion of the city, which has become difficult to manage. There is a large number of driving forces behind the sprawl, but one of the major reasons behind this change is the population growth, particularly after the 1980's.

Lake Mogan and its surrounding, is a part of a main basin system in Ankara and one of the important natural areas supporting the ecological sustainability of the city. It is subject to intense urbanization and industrial pollution. As a result of dense highway traffic networks, lack of infrastructure, extensive agriculture, intense second housing development and construction enterprises, the study area has been negatively affected. Deterioration of water quality and size of the lake, degradation of wetland and aquatic ecosystem, destruction of flora and fauna are the primary issues in the study area. Consequently, the area experienced extensive conversion to urban land cover in the last few decades.

Like all specially protected areas, Lake Mogan and surroundings are dynamic areas open to influence of human factors. Protecting and enhancing these outstanding ecosystems are essential to the benefit of human communities. It is necessary to preserve natural habitats of high ecological value and maintain and restore ecological continuties between ecosystems. Compiling information on the specially protected areas is a fundamental process which allows planners and decision makers to correct for future action in light of past experience.

Detecting past changes and predicting future changes play a key role in decision making and long term planning for future. In this study, a combined use of remote sensing, GIS and CA-Markov Chain modelling techniques were employed in assessing the trends of past urban land cover changes and projecting the land change until 2029 for Mogan Lake and its surroundings.

Both the visual interpretation of classified images and statistical data about the spatial distribution of different land use/cover changes confirm that there is a significant effect of urbanization. Due to this, 393 ha agricultural land and 70 ha lake area has been lost due to unplanned urbanization and industrialization since 1975. On the other hand, settlements increased by 201 ha during the 34 years period.

Gölbaşı District is one of the fastest growing quarters in Ankara. Many parts of the district are unplanned. Results of our study show that Lake Mogan and its surrounding situated in Gölbaşı have been experiencing extensive conversion of agricultural land, water bodies, wetlands and vegetation land cover types. Conversions involving urban development and agriculture classes represent the most significant changes.

The modelling result indicated that urban growth in the study area might continue to expand further in the future and might have an irreversible impact on land resources unless some preservation mechanism is enacted. Future land use/cover changes would cause further impact on the ecological process and increase the pressure of agriculture on lake and wetland because local authorities lack any socio-economic land use management plans based on ecological factors and geo-spatial information.

The outcomes of this present research will contribute shaping the form of the district in a planned manner. The city planners as well as decision makers can initiate plans based on the outcome of this research. This kind of research can be remarkable in Mogan and the surrounding environment much more livable and planned city of Ankara in the near future.

\section{References}

Antrop, M.: Landscape change and the urbanization process in Europe. Landscape Urban. Plan., 67, 9-26 (2004).

Araya, Y.H. and P. Cabral: Analysis and modelling of urban land cover change in Setúbal and Sesimbra, Portugal. Remote. Sens., 2, 1549-1563 (2010).

Arora, T., A. Mishra, G. Matta, A. K. Chopra, A. Kumar, D.R. Khanna and 
V. Kumar: Pollution load assessment and potential environmental risks of composite industrial effluents discharged from SIIDCUL Integrated Industrial Estate, Haridwar (Uttarakhand), India. J. Environ. Biol., 38, 205-216 (2017).

Aspinall, R. J., and M. J. Hill.: Land Use Change: Science, Policy and Management. CRC Press, Boca Raton, Florida, USA(2008).

Baker, W.L.: A review of models of landscape change. Landscape Ecol., 2,111-133(1989).

Barbaros, F., C.P. Cetinkaya and N. Harmancioglu: Effects of human activities on water quality: A case study - Mogan and Eymir Basin. Internatıonal Congress on River Basin Management, pp. 438-452 (2007).

Beklioglu, M.: Eymir ve Mogan Gölleri. (In Turkish). Türkiye Mühendislik Haberleri, 409, 22-23 (2000).

Brown, D., A. Delgado, R. Moss and F. Sedano: Need and options for subnational scale land-use and land-cover scenarios for the United States. U.S. Global Change Research Program (2015).

Chapin, III F.S., P.A. Matson and P. Vitousek: Principles of Terrestrial Ecosystem Ecology. Springer Science, Stanford, USA (2011).

Cohen, J.E.: The Future of Population. In: What the Future Holds: Insights from Social Science (Eds.: R.N. Cooper and R. Layards). MIT Press, Cambridge, MA., pp. 29-75 (2002).

Drobne S. and A. Lisec: Multi-attribute decision analysis in GIS: Weighted linear combination and ordered weighted averaging. Informatica, 33, 459-474 (2009).

Durmusoglu, Z.O.: Analyzing the land use/cover changes in Lake Mogan using remote sensing. $27^{\text {th }}$ ECLAS Conference Proceedings, Istanbul, Turkey (2010)

Epstein, J., K. Payne and E. Kramer: Techniques for mapping suburban sprawl. Photogramm. Eng. Rem. S., 63, 913-918 (2002).

Fakıoglu, O. and S. Pulatsu: Mogan Gölünde (Ankara) Bazı Restorasyon Önlemleri Sonrası Dış Kaynakıı Fosfor Yükünün Belirlenmesi. (In Turkish). Yüzüncü Yıl Üniversitesi Ziraat Fakültesi Dergisi Yayınları, 15, 63-69 (2005).

Foley, J.A., S. Levis, M.H. Costa, W. Cramer and D. Pollard: Incorporating dynamic vegetation cover within global climate models. Ecol. Appl., 10, 1620-1632 (2000).

Foley, J.A., R. DeFries, G.P. Asner, C. Barford, G. Bonan, S. Carpenter, F.S. Chapin, M. Coe, G.C. Daily, H.K. Gibbs, J.K. Helkowski, T. Holloway, E.A. Howard, C.J. Kucharik, C. Monfreda, J.A. Patz, I.C. Prentice, N. Ramankutty and P. Snyder: Global consequences of land use. Science, 309, 570-574 (2005).

Fortin, M.J., B. Boots, F. Csillag and T.K. Remmel: On the role of spatial stochastic models in understanding landscape indices in ecology. Oikos, 102, 203-212 (2003).

He, C., H. N. Okada, Q. Zhang, P. Shi and J. Li: Modelling dynamic urban expansion processes incorporating a potential model with cellular automata. Landscape Urban. Plan., 86, 79-91 (2008).

Karul, C., S. Soyupak, A.F. Çilesiz, N. Akbay and E. Germen: Case studies on the use of neutral networks in eutrophication modeling. Ecol. Model., 134, 145-152 (2000).

Klumpp, K., S. Fontaine, E. Attard, G. Gleixner, X. Leroux and J.F. Soussana: How land use change shifts C-Poor, productive ecosystems to C-Rich unproductive ecosystems and vice versa? J. Ecol., 91, 867-885 (2009).

Lambin, E.F. and H.J. Geist: Land-use and land-cover change. Local processes and global impacts. Berlin, Springer (2006).

Lambin, E.F., M. Rounsevell and H. Geist: Are current agricultural land use models able to predict changes in land use intensity? Agr.
Ecosyst. Environ., 1653, 1-11 (2000).

$\mathrm{Li}, \mathrm{X}$. and A Yeh: Neural-network-based cellular automata for simulating multiple land use change using GIS. Int. J. Geogr. Inf. Sci., 16, 323343 (2002).

Long, H., G. Tang, X. Li and G.K. Heilig: Socio-economic driving forces of land-use change in Kunshan, the Yangtze river delta economic area of China. J. Environ. Manage., 83, 351-364 (2007).

Lunetta, R.S. and C. Elvidge: Remote Sensing Change Detection. Taylor \& Francis. (1999)

Matheussen, B., R.L. Kirschbaum, I.A. Goodman, G.M. O'Donnell and D.P. Lettenmaier: Effects of land-cover change on stream flow in the interior Columbia River Basin. Hydrol. Process., 14, 867-885 (2000).

OCKKB: T.C. Çevre ve Orman Özel Çevre Koruma Kurumu Başkanlığı, II Durum Raporu. (In Turkish) (2010).

Pielke, Sr. R.A.: Land use and climate change. Science, 310 (5754), 1625-1626 (2005).

Pouyat, R.V., K. Belt, D. Pataki, P. Groffman, J. Hom and L. Band: Urban land-use change effects on biogeochemical cycles. In: Terrestrial ecosystems in a changing world. Global Change, The IGBP Series. (Eds.: J.G. Canadell). Springer, Berlin-Heidelberg-New York., p. 45-58. (2007).

Pulatsu, S. and F. Aydin. Water quality and phosphorus budget of Mogan Lake, Turkey. Acta. Hydroch. Hydrob., 25, 128-134. (1997).

Rizvi, I.A. and B.K. Mohan: Object-based Image analysis of highresolution satellite images using modified cloud basis function neural network and probabilistic relaxation labeling process. IEEE T. Geosci. Remote. 49, 4815-4820 (2011).

Rizzoli, A.: Land use change and biodiversity conservation in the Alps. J. Mountain Ecol., 7, 1-7. (2003).

Sala, O.E., F.S. Chapin, J.J. Armesto, E. Berlow, J. Bloomfield, R. Dirzo, E. Huber-Sanwald, L.F. Huenneke, R.B. Jackson, A. Kinzig, R. Leemans, D.M. Lodge, H.A. Mooney, M. Oesterheld, N.L. Poff, M.T. Sykes, B.H. Walker, M. Walker and D.H. Wall: Global biodiversity scenarios for the year 2100 . Science, $287,1770-1774$ (2000).

Schneck, R., C.H. Reick, J. Pongratz and V. Gayler: The mutual importance of anthropogenically and climate-induced changes in global vegetation cover for future land carbon emissions in the MPI-ESM CMP5 simulations. Global Biogeochem. Cy., 29, 1816 $1829(2015)$

Singh, A.: Digital change detection techniques using remotely-sensed data. Int. J. Remote Sens., 10, 989-1003 (1989).

Tu, M.: Assessment of the effects of climate variability and land-use change on the hydrology of Meuse River Basin. PhD Thesis, Netherland: UNESCO-IHE Institute for Water Education (2006).

Turner, II B.L. and W.B. Meyer: Global land-use and land-cover change: An overview. In: Changes in land use and land cover: A global perspective (Eds.: W.B. Meyer and B.L Turner II) Cambridge University Press, . Cambridge, pp. 3-10 (1994).

Veldkamp, A. and E.F. Lambin: Predicting land-use change. Agr. Ecosyst. Environ., 85, 1-6 (2001).

Verburg, P.H.: Simulating feedbacks in land use and land cover change models. Landscape Ecol., 21, 1171-1183 (2006).

Verburg, P.H., J. Van de Steeg, A. Veldkamp and L. Willemen: From land cover change to land function dynamics: A major challenge to Improve land characterization. J. Environ. Manage., 90, 1327$1335(2009)$

Verburg, P.H., K. Neumann and L. Nol: Challenges in using land use and 
land cover data for global change studies. Glob. Change Biol., 17, 974-989 (2010).

Vitousek, P.M, H.A. Mooney and J.M. Lubchenco Jmelillo: Human domination of earth's ecosystems. Scince, 277, 494-499 (1997).

Weng, Q.: Land use change analysis in the Zhujiang Delta of China using satellite remote sensing, GIS and stochastic modelling. J. Environ.
Manage., 64, 273-284 (2002).

Weng, Y.: Spatiotemporal changes of landscape pattern in response to urbanization. Landscape Urban. Plan., 81, 341-353 (2007).

Zhou, W., A. Troy and M. Grove: Modeling residential lawn fertilization practices: integrating high resolution remote sensing with socioeconomic data. Environ. Manage., 41, 742-752 (2008). 